\title{
Preparation of modified oil road bitumen
}

\author{
Oleg Karimov ${ }^{1, *}$, Gulzada Shakulikova ${ }^{2}$, Nasima Ishmukhamedova $^{3}$, and Eduard Karimov ${ }^{4}$ \\ ${ }^{1}$ Russian Technological University, Vernadsky Avenue 78, 119454, Moscow, Russia \\ ${ }^{2}$ Atyrau University of Oil and Gas, Baymukhanov street 45a, 060027, Privokzalnyi MD Atyrau, \\ Republic of Kazakhstan \\ ${ }^{3}$ Laboratory of Engineering Profile "Petrochemistry", Atyrau University of Oil and Gas, Azattyk \\ Avenue 1, 060002, Atyrau, Republic of Kazakhstan \\ ${ }^{4}$ Ufa State Petroleum Technological University, Pr. Oktyabrya 2, 453100, Sterlitamak, Russia
}

\begin{abstract}
The aim of this work is to study the possibility of developing oil road bitumen by goudron oxidation of mixed base oils with the softening temperature of $24^{\circ} \mathrm{C}$ from the Martyshi and Mangistau deposits using vacuum residue of more than $450{ }^{\circ} \mathrm{C}$ of highly resinous oil from the Karazhanbas deposit of the Republic of Kazakhstan as an additive, elemental sulfur modifier and induction moments. Karazhanbas oil has a high content of oil tars (24.18\% wt.) and asphaltenes (4.85\% wt.). The oxidation of goudron and vacuum residue of highly resinous oil was carried out in a bubble reactor when thermostating at $200-210^{\circ} \mathrm{C}$, specific air consumption of $1.8-2 \mathrm{l} / \mathrm{min} \cdot \mathrm{kg}$. The oxidation process of the feedstock was completed when the viscosity of bitumen was reached by the ring-andball method of $32-35{ }^{\circ} \mathrm{C}$. Oil bitumen was obtained with the following technological characteristics: penetration at $25^{\circ} \mathrm{C} 105 \mathrm{~mm}$, melting point $51{ }^{\circ} \mathrm{C}$, tensibility at $25{ }^{\circ} \mathrm{C} 67 \mathrm{~cm}$, flash point $230{ }^{\circ} \mathrm{C}$, brittle temperature minus $15^{\circ} \mathrm{C}$.
\end{abstract}

\section{Introduction}

Modern road construction places high demands on road-building materials, especially binders, and in particular on bitumens for bituminous concrete. In the Republic of Kazakhstan, this is especially true in connection with the commissioning of new highways under the Nurly Zhol program and requirements to reduce the cost of annual repair of road topping. In this situation, the issues of production of high-quality road bitumen providing a significant increase in the durability of bituminous concrete pavement are quite acute.

The main process for production of bitumen in the CIS countries is oxidation, i.e. blowing the goudron (road tar) with air at temperatures of $230^{\circ}-300^{\circ} \mathrm{C}$ for 12 hours. The oxidation process will remain the main one at least in the short term since the deepening of oil refining which contributes to the transition to bitumen production (primarily road bitumen) in the process of deep vacuum distillation, is slow. It should be noted that the oxidation process bitumen is better suited to the current CIS standard [1]. The main factors that determine the properties of oxidized bitumen are the group composition of the

\footnotetext{
* Corresponding author: karimov.oleg@gmail.com
} 
feedstock and the technological parameters of oxidation as well as the way to change the quality indicators of oxidized bitumen by introducing modifiers and structure-forming agents in the feedstock $[2,3]$. The low plasticity of oxidized bitumen obtained only from goudron is due to the increased content of asphaltenes which form a fairly rigid structural network. Therefore, bitumen is structured to a greater extent by oil tars than by asphaltenes [4].

It should be noted that road binders traditionally produced by conventional oxidation technology, for several reasons, are becoming increasingly unsuitable for the construction of durable road surfaces. They are characterized by insufficient resistance to oxidative aging processes, have low values of extensibility index (before and after aging) and poorly adhere to acidic mineral materials. This overall leads to leaching of individual particles of the road surface under the action of loads [5].

One of the main ways to increase the service life of bituminous concrete pavement is to change the structure and properties of organic binders used for its preparation $[6,7]$.

On of the most challenge for the bitumen industry is that the petrochemical industry is becoming more and more efficient in breaking down higher chain hydrocarbons to lower chain hydrocarbons with higher added value than bitumen. This has an effect on the availability and quality of bitumen. The use of alternative sustainable binders broadens the availability.

The most common methods are modifications with fillers, surfactants and polymer additives or waste from their production including plant origin, for example, lignosulfonates [8-11].

Raw materials for the production of bitumen include materials containing substances with a high viscosity, asphaltene components. They are obtained from waste generated during the processing of oil. Today, instead of natural production, the most common is the technology for the production of oil bitumen by industrial enterprises from waste generated during the processing of crude oil.

The oil and gas industry in the Caspian Sea region (Atyrau and Mangistau oblasts of the Republic of Kazakhstan) is composed of oil and gas development enterprises, oil and gas refineries and oil and gas transporting corporations. Oil development is the predominant activity in Atyrau oblast, while co-development with gas is pursued in Mangistau oblast.

The richest oilfields in Republic of Kazakhstan is Tengiz, Zhanazol, Karachaganak, Uzen, Martyshi and Zhetybay. Some of the local crude oils are very heavy and required special processing capabilities.

Over the past four decades the ability of sulfur to modify and enhance the properties of material have been extensively studied and exploited. Recently the amount of sulfur produced from oil and gas industries has considerably increased resulting in drop in market prices. Extremely large quantities of sulfur are produced as a byproduct and hence development of new applications of sulfur has become fundamental.

This paper shows the possibility of developing oil road bitumen by goudron oxidation using highly resinous oil as an additive, elemental sulfur modifier and induction moments.

\section{Materials and Methods}

To develop oil road bitumen, the goudron of mixed base oil from the Martyshi and Mangistau deposits of the Republic of Kazakhstan with the softening temperature of $24^{\circ} \mathrm{C}$, the vacuum residue of $>450{ }^{\circ} \mathrm{C}$ of highly resinous oil from the Karazhanbas deposit of the Republic of Kazakhstan, the elemental sulfur modifier of the Tengiz oil and gas condensate plant and the additional structure-forming agent in the form of induction moments were used. 
The characteristics of goudron of mixed base oils of the Martyshi and Mangistau deposits in the ratio of 1:1 are presented in Table 1.

Table 1. Goudron of mixed base oil of the Martyshi and Mangistau deposits.

\begin{tabular}{|c|c|}
\hline Parameters & Values \\
\hline Density $\mathrm{p}^{20}{ }_{4}, \mathrm{~kg} / \mathrm{m}^{3}$ & 966.5 \\
\hline Molecular weight & 675 \\
\hline Coke value, mass, \% & 5.8 \\
\hline Content, mass, \% & \\
\hline Ultimate composition: & \\
\hline carbon & 83.8 \\
\hline hydrogen & 13.6 \\
\hline sulphur & 0.3 \\
\hline Volume components: & \\
\hline oils & 67.3 \\
\hline oil tars & 23.4 \\
\hline asphaltenes & 8.1 \\
\hline
\end{tabular}

Physicochemical parameters of dehydrated and desalted highly resinous oil of the Karazhanbas field and the oil of the Kalamkas field as a comparative analysis are presented in Table 2.

The oxidation of goudron and vacuum residue of $>450{ }^{\circ} \mathrm{C}$ of highly resinous oil was carried out in a bubble reactor when thermostating at $200-210{ }^{\circ} \mathrm{C}$, specific air consumption of $1.8-2 \mathrm{l} / \mathrm{min} \cdot \mathrm{kg}$.

Table 2. Physicochemical characteristics of oils.

\begin{tabular}{|c|c|c|}
\hline \multirow{2}{*}{ Parameters } & \multicolumn{2}{|c|}{ Oil deposits } \\
\cline { 2 - 3 } & Karazhanbas & Kalamkas \\
\hline Stratum depth, $\mathrm{m}$ & $285-290$ & $845-858$ \\
\hline Specific weight, $\rho^{20}{ }_{4}$ & 0.9418 & 0.9217 \\
\hline Molecular weight & 384 & 285 \\
\hline Content, \% mass: & & 12.14 \\
\hline oil tars & 24.18 & 1.48 \\
\hline asphaltenes & 4.85 & 3.18 \\
\hline paraffin & 1.50 & 84.10 \\
\hline Ultimate composition, \% mass & & 12.00 \\
\hline $\mathrm{C}$ & 82.51 & 0.64 \\
\hline $\mathrm{H}$ & 11.79 & 1.62 \\
\hline $\mathrm{N}$ & 0.85 & 1.64 \\
\hline $\mathrm{S}$ & 2.55 & \\
\hline $\mathrm{O}$ & 2.30 & 14.76 \\
\hline Fractional yield, \% mass: & & 5.43 \\
\hline$<200{ }^{\circ} \mathrm{C}$ & 6.00 & 8.36 \\
\hline $200-250^{\circ} \mathrm{C}$ & 3.00 & 11.21 \\
\hline $250-300^{\circ} \mathrm{C}$ & 6.84 & 6.86 \\
\hline $300-350^{\circ} \mathrm{C}$ & 10.11 & 4.38 \\
\hline $350-400{ }^{\circ} \mathrm{C}$ & 5.13 & \\
\hline $400-450^{\circ} \mathrm{C}$ & 12.15 & \\
\hline
\end{tabular}

During the oxidation process, the reaction mixture was two times subjected to induction treatment. The oxidation process of the feedstock was completed when the viscosity of bitumen was reached by the ring-and-ball method of $32-35^{\circ} \mathrm{C}$. Then the reaction mixture 
was decanted in a laboratory mixer and allowed to cool to $100-120{ }^{\circ} \mathrm{C}$. After that, the heating was turned on, and molten sulfur was introduced under intense dispergation. Thermostating of the reaction mixture ranged within the permissible rates of working with elemental sulfur. Dispergation time depends on the readiness of the resulting target product.

\section{Results and discussion}

From Table 2 it follows that the Karazhanbas oil chosen as an additive to the goudron for manufacturing oil bitumen, unlike the oil of the Kalamkas field, has a high content of oil tars, (24.18 \% wt.) and asphaltenes (4.85\% wt.). It should be noted that asphaltenes, in turn, are stabilizers of molecular weight growth and as a whole make a certain contribution in improving the technological parameters of the obtained bitumen [12-15].

Asphaltenes comprise 5-25\% the composition of bitumen, and in terms of building, a combination of compressed aromatic rings with aliphatic lateral chains and the number of aromatic rings is 6-20 and even sometimes more of this.

Asphaltene rate in bitumen has many effects on rheological properties of bitumen. The higher the bitumen asphalt, the more the stiffness of the bitumen, and subsequently the degree of penetration would be less. In addition, it will result in a greater softening point and more penetration of bitumen.

The technological parameters of the obtained bitumen binder are presented in Table 3 .

It should be noted the important role of induction moments. As a result of the creation of induction moments, the volume of chemically reactive bicycloaromatic and polycycloaromatic hydrocarbons increases (it was confirmed by instrumental analysis) which contribute to accelerating the formation of high molecular compounds. This leads to an increase in the molecular weight of oxidizable raw materials thanks to which the technological characteristics of the resulting bitumen are improved.

Table 3. Test results of a sample of oil bitumen obtained in a laboratory.

\begin{tabular}{|l|c|c|}
\hline \multicolumn{1}{|c|}{ Parameters } & $\begin{array}{c}\text { GOST } \\
\mathbf{2 2 2 4 5 - 9 0}\end{array}$ & $\begin{array}{c}\text { Bitumen grade } \\
\text { BN 80/120 }\end{array}$ \\
\hline Needle penetration depth, mm & & 105 \\
\hline at $25^{\circ} \mathrm{C}$ & $91-130$ & 32 \\
\hline at $0{ }^{\circ} \mathrm{C}$, min & 28 & 51 \\
\hline Softenig point, ${ }^{\circ} \mathrm{C}$, min & 43 & 67 \\
\hline Tensibility, cm, min: & & 4.2 \\
\hline at $25{ }^{\circ} \mathrm{C}$ & 65 & 230 \\
\hline at $0{ }^{\circ} \mathrm{C}$ & 4.0 & -15 \\
\hline Flash point, ${ }^{\circ} \mathrm{C}$, min & 230 & \\
\hline Brittle temperature, ${ }^{\circ} \mathrm{C}, \min$ & -17 & \\
\hline
\end{tabular}

From the data of Table 3 it follows that as a result of this work oil bitumen was obtained with the following technological characteristics: penetration at $25{ }^{\circ} \mathrm{C}-105 \mathrm{~mm}$, melting point $51{ }^{\circ} \mathrm{C}$, tensibility at $25^{\circ} \mathrm{C}-67 \mathrm{~cm}$, flash point $230{ }^{\circ} \mathrm{C}$, brittle temperature minus 15 ${ }^{\circ} \mathrm{C}$, which corresponds to GOST 22245-90 for the bitumen od grade BN 80/120.

\section{Conclusions}

Thus, the natural composition of the bitumen largely controls the properties of the modified product. The composition of bitumen, a by-product of crude oil refining, is complex and varies with the crude oil source. 
In order to obtain highly plastic bitumen, characterized by high heat resistance and good binding properties, it is necessary to use raw materials of a certain and constant quality. Tars of heavy oils, which contain a lot of resinous and asphaltene substances, usually possess the necessary properties. In the general case, the following statement is true: the greater the asphaltene: resin ratio, the better the properties and structure of the bitumen produced.

The Karazhanbas oil chosen as an additive to the goudron for manufacturing oil bitumen has a high content of oil tars and asphaltenes. The high content of high molecular weight components in the oil of the Karazhanbas field, prone to associative interactions and structure formation in tandem with goudron of mixed base oils of Martyshi and Mangistau makes it possible to obtain oil road bitumen (petroleum asphalt). An important role in this is played by the addition of a technogenic modifier, i.e. elemental sulfur and the introduction of induction moments, which leads to an increase in the technological parameters of the target product - a bituminous binder.

Considering that highly resinous oil which is economically unprofitable for processing was used to produce bitumen, the developed technology makes it possible to rationally utilize the by-products of oil and gas processing, which is economically and environmentally feasible.

\section{References}

1. M. Porto, P. Caputo, V. Loise, S. Eskandarsefat, C.O. Rossi, Appl. Sci., 9, 742 (2019) https://doi.org/10.3390/app9040742

2. A.O. Shrubok, E.I. Grushova, Petroleum Chemistry, 57 868-873 (2017)

3. A.F. Kemalov, R.A. Kemalov, I.M. Abdrafikova, P.S. Fakhretdinov, D.Z. Valiev, Advances in Materials Science and Engineering (2018) https://doi.org/10.1155/2018/7913527

4. S.H. Changm P.R. Robinson, Practical Advances in Petroleum Processing (Springer, New York, 2006)

5. M. Borris, H. Osterlund, J. Marsalek, M. Viklander, Science of The Total Environment, 573, 212-221 (2016)

6. M. Sulyman, M. Sienkiwicz, J.T. Haponiuk, International J. Of Environmental Science and Development, 5, 444-454 (2014)

7. K. M. Andrews, P. Nanjappa, Roads and Ecological Infrastructure: Concepts and Applications for Small Animals (JHU Press, Baltimor, 2015)

8. B. He, J. Yu, Y. Gu, R. Zhuang, Y. Sun, Construction and Building Materials, 180, 342-350 (2018)

9. B. He, J. Yu, W. Hu, X. Wan, Z. Wu, J. of Wuhan University of Technology-Mater. Sci. Ed., 34, 446-452 (2019)

10. W. Guo, X. Guo, M. Chang, W. Dai, Materials, 11, 2328 (2018) https://doi.org/10.3390/ma11112328

11. G.V. Konesev, M.I. Zhestovskih, G.A. Teptereva, R.A. Ismakov, SOCAR Proceedings 2, 6-10 (2018) https://doi.org/10.5510/OGP20180200344

12. D. Lesueur, Advances in Colloidal and Interface Science, 145, 42-82 (2009)

13. X. Lu, P. Redelius, Energy \& Fuel, 20, 653-660 (2006)

14. C. Stachowiak C., J.-R. Vigue, J.-P.E. Grolier, Langmuir, 21, 4824-4829 (2005)

15. S. Fakher, M. Ahdya, M. Elturki, A. Imqam, J. of Petrol. Explor. and Production Technology (2019) https://doi.org/10.1007/s13202-019-00811-5 